\section{Material aesthetics and agency: Alexander Dorner and the stage-managed museum}

\author{
Sandra Karina Löschke
}

I intended to show that there are much more profound forces of change at work in life, which unite past and present in a much intenser way, than we are accustomed to see. This wholly relative, wholly dynamic interpenetrative history has a new power to direct us. History indeed is able to tap a substratum of positive, new - and badly needed - energies for our conduct of all life, artistic and otherwise. (Dorner 1958: 18)

At stake for the museum in the early 1920s, Alexander Dorner suggested, was much more than art historical erudition and connoisseurship but the adequate resolution of the only thing that mattered - "ourselves and our vital problems" (1958: 147). The purpose of the museum was to aid the improvement of selfawareness and a deeper understanding of the present situation, he insisted, and this could only be accomplished if "the energies that, surging up from the past, have invaded our own lives" (147) were uncovered. It was apparent to him that the museum would have to utilise "all possible sensory and intellectual resources of representation” (146) to achieve this aim.

The particular challenge identified by Dorner appeared to be one of method - how could historical and cultural content be mediated adequately in order to become relevant for the present? Something beyond scientific organisation and representation was at issue - something that materialised immaterial energies that lay dormant in our cultural heritage and that, once activated, had the capacity to improve human life and facilitate social progress. It is Dorner's own curatorial response to these challenges that is under investigation in this study, which focuses on Dorner's reorganisation of the collections at the Provinzialmuseum Hannover during the 1920s.

Dorner's grouping of period works in discrete Atmosphärenräume (atmosphere rooms $)^{1}$ and the introduction of an evolutionary itinerary have been considered conventional and comparable to earlier reorganisation efforts (Flacke 1993: 137; Klonk 2009: 94; Scholl 1995). Similarly, his concurrent deployment of atmospheric immersion and an evolutionary itinerary have been seen as incompatible and a grave inconsistency in his curatorial approach: on one hand, the audience's identification with an epoch precludes the possibility of a continuous consciousness - the viewer is expected to empathise; on the other hand, it is precisely the cognition of a historic continuity that is evoked with the realisation of a concept of historic development (Flacke-Knoch 1986/87: 137).

Counter to these arguments, this study suggests that it is possible to attain a more nuanced reading of Dorner's strategies by pursuing a detailed analysis of elements of his curatorial practice - in particular, central display elements such as the use of wall colour and reframing. When unravelled in relation to his museum guidebooks and other information material, his practice emerges as a calculated staging of intellectual insights and sensory impressions. However subtle, Dorner's strategies marked a turning point in the presentation of artworks in museums by going beyond issues of representation and taste that governed the work of his peers. ${ }^{2}$ His stage-managed environments transformed the way the audience interrelated
1 Dorner used the term atmosphere room to describe the grouping of artworks from historic periods/styles in discrete rooms. Unlike period rooms, these were not stylistically homogenous. They were given an identity through colourful appointment and fitted with modern furniture and everyday objects to reflect the self-understanding and spatial conceptions of their respective time as seen from a present perspective. See Dorner 1924

2 For a discussion of Dorner's curatorial work in the wider context of other museum re-organisations see Scholl 1995; Flacke 1993. 
with the art objects presented to them - a material dialectic intended to promote empathy and immersion whilst simultaneously encouraging active reception and awareness of reality.

\section{The state of German museums in the early 1920s: Excess and disorientation}

Having spent his early years at the Provinzialmuseum cataloguing the drawing and painting collections as a research assistant, Dorner had formed a comprehensive idea about the museum's holdings when he began to restructure the collections and gallery spaces of the Provinzialmuseum in 1923. At the time, the collections were still in a state of disarray. More reminiscent of a curiosity cabinet than an art collection, the Provinzialmuseum was described by staff as a "trash room" (Flacke 1992: 51) where one could find an altar next to a stuffed boar and a painting. The museum's "high walls", as Dorner later observed, "threatened to collapse under the load of the good and the bad” (Katenhusen 1993: 71).

As a consequence of complex ownership structures and loan agreements (see Cauman 1958: 30-31), the Provinzialmuseum functioned essentially as a depository for an array of diverse objects that were exhibited as singular items without meaningful interrelations - a "loose aggregate", as Dorner termed it (1958: 16). ${ }^{3}$ Visitors found themselves not only overwhelmed by the plethora of objects on display, but also entirely left to their own devices in engaging in a meaningful way with the diverse exhibits they had encountered.

The situation in Hannover was symptomatic of the wider museum landscape at the time that was caught between tradition and rapid change (Mai 2010: 365). Museum reform efforts had already commenced in the 1880s (Joachimides 2001), but in the more radicalised political climate of the early Weimar republic, the call for "the activation of museums as educational establishments for the people" (Taut 1918) grew louder. The museum, increasingly regarded as a predominantly educational institution, had to leave behind its passive position and engage in what Dorner described as an active museum practice, whose primary goal was to find new ways to evaluate art collections for the general public - ways that would make art historical developments not only visible but comprehensible (see Dorner 1924). This active practice meant a shift of attention from the representation of objects to the mediation of ideas inherent in these objects.

\section{Dorner's Raumbild concept}

3 Owners often insisted on the separate display of their collections. They often resisted the relegation of qualitatively less valuable works to "study collections" forcing museums to display the entire collection. See Alexander Dorner's proposal for a re-organisation of the Duke of Cumberland's collections, dated 3 April 1923 (Niedersachsisches Landersarchiv: Hann.152 ACC. 2006/013 Nr.1)

$4 \quad$ In the English-language publication of his book The way beyond 'art', which summarises his life's work both as an art historian and as a museum director, Dorner described the idea of Raumbild more loosely as "reality concept" (1958: 17).

According to Dorner, art and culture were primarily manifestations of the prevalent historic conceptions of space and thus represented immediate expressions of how people conceived of themselves as being in space and time, and in relation to objects and one another. Thus for Dorner, the history of art and architecture mapped the history of human relations to space and materialised the image of self that was formed in relation to it. Thematised under the heading of Raumbild ${ }^{4}$ the idea of historically evolving space-time relations was highly implicated in Dorner's curatorial work. Literally translated as both spatialised image and image of space, the notion of Raumbild resides between object and image, between the perceived and the imagined, between the material and the immaterial. In the same way that a Raumbild could be articulated in an artwork, its underlying concept could also be rematerialised as part of the exhibition room. The Raumbild's fluctuation between image and space can be seen as the enabling assumption for Dorner's curatorial practice. 
Dorner's concern with changing and increasingly dynamic concepts of space can be traced throughout his writings, in which he developed an extensive vocabulary around this theme. In his 1923 publication Die Romanische Baukunst in Sachsen und Westfalen (Roman Architecture in Saxony and Westphalia), the changing interrelations between Baukörper (built object), and Raum (space) towards their equilibrium in the concept of Raumbau (space building) were explored as the decisive aspect in the transition from the Roman to the Gothic Raumbild. The accentuation of the built object customary in Roman art, Dorner noted, was reversed in Westphalian Gothic where space assumed an all-embracing unity and "the built object recede[d] into the background as subservient" (1923: 9). This shift in emphasis from object to space was paralleled in the sensory impressions imparted by the architecture - the sense of "expansion and calm" apparent in Roman architecture was replaced with "intensity and movement" in Gothic architecture (8). ${ }^{5}$

Dorner's correlation of spatial and empathic conditions is not new and can be linked to his self-confessed partisanship of Alois Riegl - an enthusiasm he developed during his studies in Berlin under Adolph Goldschmidt (Dorner 1958: 15). In a series of lectures on the origins of Baroque art in Rome, Riegl had advanced a parallelism between Tiefraum (deep space) and Empfindung (sensation) that he termed Raumwirkung (spatial effect) (1908: 43). Observing a tendency to only look at the physical in architecture, Riegl suggested that beyond architectural composition, buildings also had a psychological effect upon us. In other words, it was possible for the viewer to receive sensory impressions from the building that pointed to an intimate relationship between architectural composition and reception.

Exclusively focused on historic art, Riegl's art philosophy did not offer a model for the art and life of the present. Thus when it came to dealing with the inclusion of contemporary art, Dorner found that he could not rely on Riegl to provide a theoretical basis for the museum re-organisation and the practical curatorial challenges at hand (see Dorner 1958: 16).

Inspired by the dynamic space-time experiences of the modern world, many of the avant-garde works Dorner acquired for the museum were informed by the emerging imagination of a four-dimensional space prompted by scientific discoveries (the discovery of x-rays, electricity, Einstein's theory of relativity, and other scientific advances) and promoted radical ideas based upon energetic interrelations between human beings and their environment (see Henderson 1990). In Dorner's own words:

We feel that the capture of our environment from a rigid, fixed standpoint, as in the perspectival image construction, results in a constricted space stage (Raumbühne) with massive scenery... captured only in front elevation which no longer correlates to the expansiveness of the space in which we move. (ca. 1926: 2)

To support a wider understanding of contemporary art and its promotion of a new Raumbild, Dorner set out to materialise the dynamic interrelations that inspired these works and make them comprehensible as part of a larger historic development.
5 Yet the central problem of Raumbau (space building), Dorner suggested, was not fully addressed in German Renaissance architecture; only Italian Renaissance architecture resolved "the problem of the equal confluence of Einheitsraum (unified space) and Einheitsmasse (uniform mass)" (1923: 10). 


\section{Materialising the energies of the past:}

An intensely integrated knowledge

In an article Was sollen heute Kunst-Museen?, published in 1924, Dorner outlined the experiential and intellectual objectives for this curatorial strategy, which he summarised under the heading of atmosphere rooms.

The emotional objectives for the spatial arrangement of artworks were:

1. To display the individual artwork in its context in such a way that it exerts the greatest possible emotional effect.

2. In addition, the individual periods of art development should be mediated to the visitor emotionally. Through this uniformity he receives the impression of clarity and through that the feeling of stability and calm.

3. Finally, this clearly-represented sequence of art periods shall be experienced as a whole - in their transition and in the consequences of their change. (Dorner 1924)

To frame these emotional encounters, accompanying textual information was required:

1. Each individual artwork must be explained in its provenance, subject matter of its pictorial representation, and the uniqueness of its style;

2. Each artistic period must be explained in its historical facts and the achievements of its style, and;

3. The entire development of art has to be revealed as a consistent sequence of styles, that build upon another, so that the entirety will be a survey of the growth and advancement of the human spirit in the area of the plastic arts. (Dorner 1924)

In his dual focus, Dorner judiciously recognised the degree to which a re-organisation could not simply be understood as a straightforward application of scientific and aesthetic criteria to the existing collection, but that some form of synthesis of intellectual and sensory impressions had to occur to engage new audiences. The two elements - the implicit knowledge gained through emotional experience and the explicit knowledge acquired by reading - had to be "co-ordinated as smoothly as possible" (Dorner 1925: 4). Dorner did not provide much information about a rigorous methodology behind the translation of his objectives into specific curatorial choices, nor did he refer to other curatorial models or scientific research on colour or perception. Taking its clues from the above objectives, the following analysis will investigate Dorner's curatorial interventions and how they can be related to the intended emotional and intellectual effects.

\section{'Unframing’ artworks: The immersion of the viewer}

The first objective outlined in Dorner's article requested the isolation of the artwork for maximum emotional intensity. Primarily, this meant a significant reduction of the number of paintings to be hung on the wall space either as single-tiered hangings or other discrete arrangements - a form of display that was already practiced in Germany at the time. Widely-spaced and mounted at eye level, generally only one artwork occupied the visual field of the viewer, confronting him one-to-one. Once isolated, paintings were re-framed. Similar efforts had been undertaken previously by Wilhelm Bode and Ludwig Justi, both of whom abandoned elaborate, gilded frames in favour of simple, modern ones that enhanced the colours and aesthetic of the painting (Klonk 2009: 238). ${ }^{6}$ In contrast, Dorner's reframing strategies revealed 
his disinterest in the aesthetic considerations of his colleagues, and instead highlighted his attempts to reconfigure frames as conceptual devices that materialised historic conceptions of space by evoking architectural effects. This translation of an artistic Raumbild into an actual architectural arrangement is most clearly demonstrated in his treatment of paintings from major historic periods. In particular, the works of the Italian Renaissance and the Dutch Baroque which were well represented in the collections and whose underlying spatial logic was discussed in detail in Dorner's museum guide books. They were exemplary for his use of sophisticated framing detail to attain spatial impact, set these styles apart from their predecessors, or highlight regional differences.

The Italian Renaissance paintings were discussed at the beginning of Part II of Dorner's museum guide which covered the period "From the Renaissance to 1800" (1930, part II: 1). Focussing on "the registration of external appearance" (1927: 10), Dorner suggested that these works represented a decisive break with the medieval desire to reflect what was spiritual and hence beyond sensory perception. To him, Renaissance art almost signified a reversal of medieval conceptions of space - a turning point when "the capture of space became the artistic objective [and] the invention of perspective ... made it possible to portray bodies and all other objects clearly delimited in space [both] in their full plasticity and in their relations to one another" (10). The increasing importance of space and nature during the Renaissance period, as Dorner understood, was clearly articulated in its documentation of "the factual matter of the visible world with sharp outlines and hard and clear colours" (ca.1930, part II: 1). The absolute viewpoint of the Renaissance Raumbild captured space as the homogenous expansion of three-dimensional volumes clearly defined solitaires layered and overlapping - and this, Dorner claimed, not only instigated a break with medieval spatial imagination, but more importantly, represented the prevalent conception of space valid up until the then-present day. In this pervasive Raumbild "the image is a view out of a window; the picture frame represents a window frame; the segment of [depicted] space lies in front of us like a stage seen from a fixed viewpoint" (Dorner 1932: 30). Even film, as Dorner later noted, had not been able to free itself from "the disadvantage, that it always generates perspectival images of space” (1932: 37).

To translate this emphasis on cubic space and geometric volumes at the level of the exhibition space, Dorner selected frames that looked like window frames (albeit modern ones). ${ }^{7}$ Intended to simulate openings in the walls of the room, the paintings were integrated as architectural elements to evoke in the viewer the impression of looking out through a window onto a stage set (see Flacke-Knock 1985: 52; Cauman 1958: 89), prescribing a statically defined position for the visitor, and materialising the Renaissance Raumbild as a viewing experience.

In contrast to his intense emphasis on frames in the Renaissance rooms, Dorner abandoned them almost entirely for the Baroque paintings of the Dutch by selecting a black-brown colour to match the edge colour of the canvases. He believed that in Dutch Baroque, the perspectival frame of the Renaissance was "fused together ... to form a total unity of space and physical masses” (ca 1930, part II: 12). To attain this homogenising spatial effect, the Dutch painters developed two main innovations that fundamentally transformed the geometric Raumbild of the previous period. According to Dorner, "tone [was] one of the means, with which Dutch art achieve[d] its new, big effects ... light-dark contrast [was] the second”(8). Masters like Rembrandt and his pupils synthesised these two techniques to achieve maximum impact. In their paintings, they sought to capture the forms of figures and objects through a variation of the degree of tonality within the brown overall
6 During his relatively short time as Director of the Städel in Frankfurt, Ludwig Justi reframed extensively, a practice he had learned during his time in Berlin as an assistant to Wilhelm Bode. The reference to Bode's reframing practices is mentioned in Klonk 2009: 238, note 68

$7 \quad$ It should be noted that in principle this treatment reflected Renaissance practices whereby frames were "invariably designed as parts of an architectural interior and were frequently meant to harmonize with door and window surrounds". Paintings were often mounted in tabernacle frames that were in keeping with the architectural styles of Gothic cathedrals and elevated the picture from the wall. Styles ranged from elaborate to simple depending on the specifications of clients. Later, Renaissance paintings were frequently re-framed to match the interiors of their owners. See Newbery, Bisacca \& Kanter 1990:11. 
colour of the painting that could be lightened completely to attain white, or darkened to attain black, as Dorner observed (8).

But it was in the fusion of spatial layers that Dorner saw Dutch painting's fundamental departure from the geometric Raumbild of the Renaissance which, he believed, still persisted in the Baroque paintings of the neighbouring Flemish provinces. In the paintings of the Dutch, the objects in the foreground gradually disappear in darkness towards the edges, leaving behind the three-partite structure of foreground, middleground and background still favoured by the Flemish. For Dorner, this effect signalled that, apart from "the unsurmountable synthesis of plasticity and spatiality, the idea of something unbounded and infinite arises" (8). The two innovations of the Dutch - tonal gradient and contrast - permitted them to step from the "stage set to unbounded scenery" (6). And although their art dealt with similar issues than the neighbouring Flemish, it is this unlimited conception of space that "allow[ed] them to go further", and that made them appear "more modern" (7) from the perspective of the fluid space-time conceptions of the present, he observed.

With the re-framing of the paintings of the Italian Renaissance and the Dutch Baroque, Dorner achieved two effects: first, the spatial concepts present in respective art periods were transferred with ease onto the actual space of the museum. In attempting to reproduce the Baroque techniques of contrast and gradient, or the Renaissance conception of geometrically framed space in the relationship between painting and wall, he paid particular attention to details that extended the geometric and visual systems of a period to the design of the exhibition space, and reproduced painterly concepts as room-embracing aesthetic systems. Since all art was regarded by Dorner as a direct articulation of a particular Raumbild, both painting and curatorial practice could be thought of as spatial practices that worked with identical 'building materials' - colour, light, tonality, contrast, volume, geometry. By materialising the concepts of painting within the arena of the museum space, a Raumbild could be experienced at the scale of the room, at one glance, upon entering, and without perceiving anything in detail.

Second, in blending the frame colour with the colour of the painting's perimeter, Dorner 'unframed' the Dutch paintings, extending the pictorial space beyond the frame and into the sphere of the viewers. ${ }^{8}$ Equally, we can speak of 'unframing' when the Renaissance picture frame became dissociated from the artwork and re-associated with the exhibition architecture as a window frame, effectively turning the painting into a 'view'. The anthropomorphising effect caused by the immediate encounter with the unframed works is comparable to that of earlier optical devices such as panoramas and dioramas which equally "cancelled the visual distance and made the viewer feel that he was right inside the picture" (Schivelbusch 1995: 217). Sloterdijk closely associated this method of 'unframing' with the phenomena of artificial immersion whose core aspect "is the potential replacement of whole environments - not only of the images, usually framed, one looks at in galleries. Immersion as a method unframes images and vistas, dissolving the boundaries with their environment” (2011 (2006): 105). In paying particular attention to the perceptual details of his display techniques, Dorner attempted to engage with the psycho-perceptual ideas also promoted by avant-garde and commercial art of his day and provided familiar connection points for new audiences. In subtle ways, the unframing techniques deployed by Dorner address what Margarete Vöhringer described as the "the technological access of the human psyche" explored by the avant garde and science at this time (Vöhringer 2007: 20).

8 It is possible to imagine that Dorner could have discarded frames entirely and matched the dark edges of the paintings with a black wall colour, which would have achieved an even greater sense of unboundedness. However, in the absence of electrical lighting at the Provinzialmusem at the time, a black wall might have darkened the rooms to an unacceptable degree. 


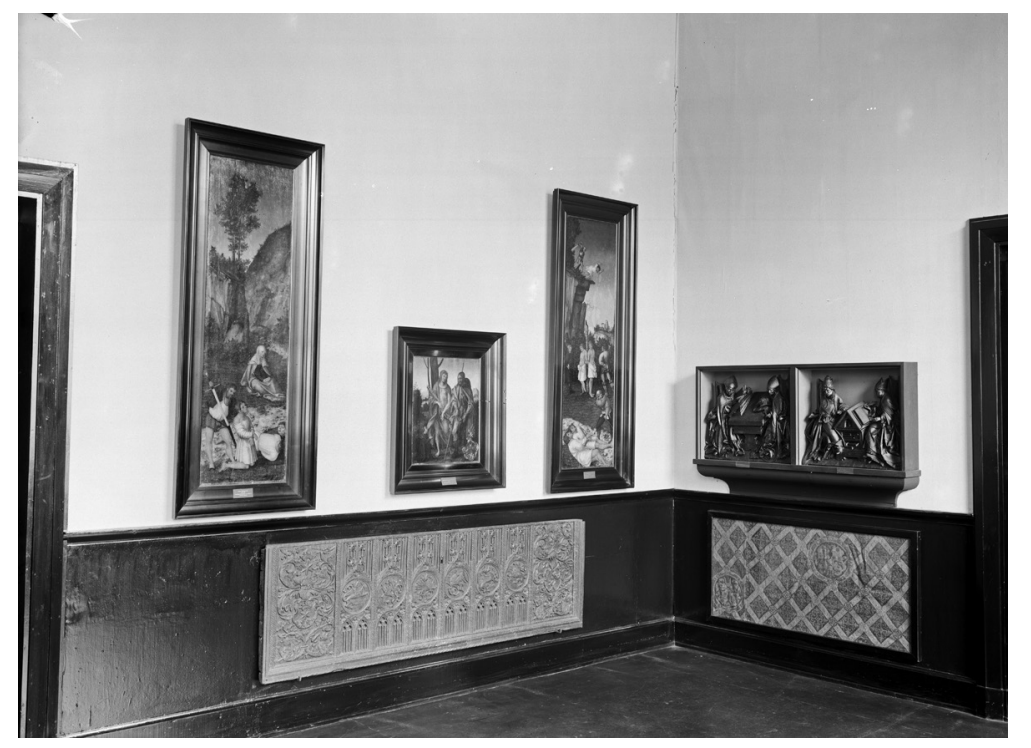

Fig.1 Alexander Dorner. Room for Italian Renaissance art after its reorganisation [photograph courtesy of Niedersäch-

sisches Landesmuseum Hannover -

Landesgalerie].

Fig.2 Alexander Dorner. Room for Dutch Baroque art after its reorganisation [photograph courtesy of Niedersächsisches Landesmuseum Hannover Landesgalerie].

Fig.3 Alexander Dorner. Room for Flemish Baroque art after its reorganisation [photograph courtesy of Niedersächsisches Landesmuseum Hannover Landesgalerie].
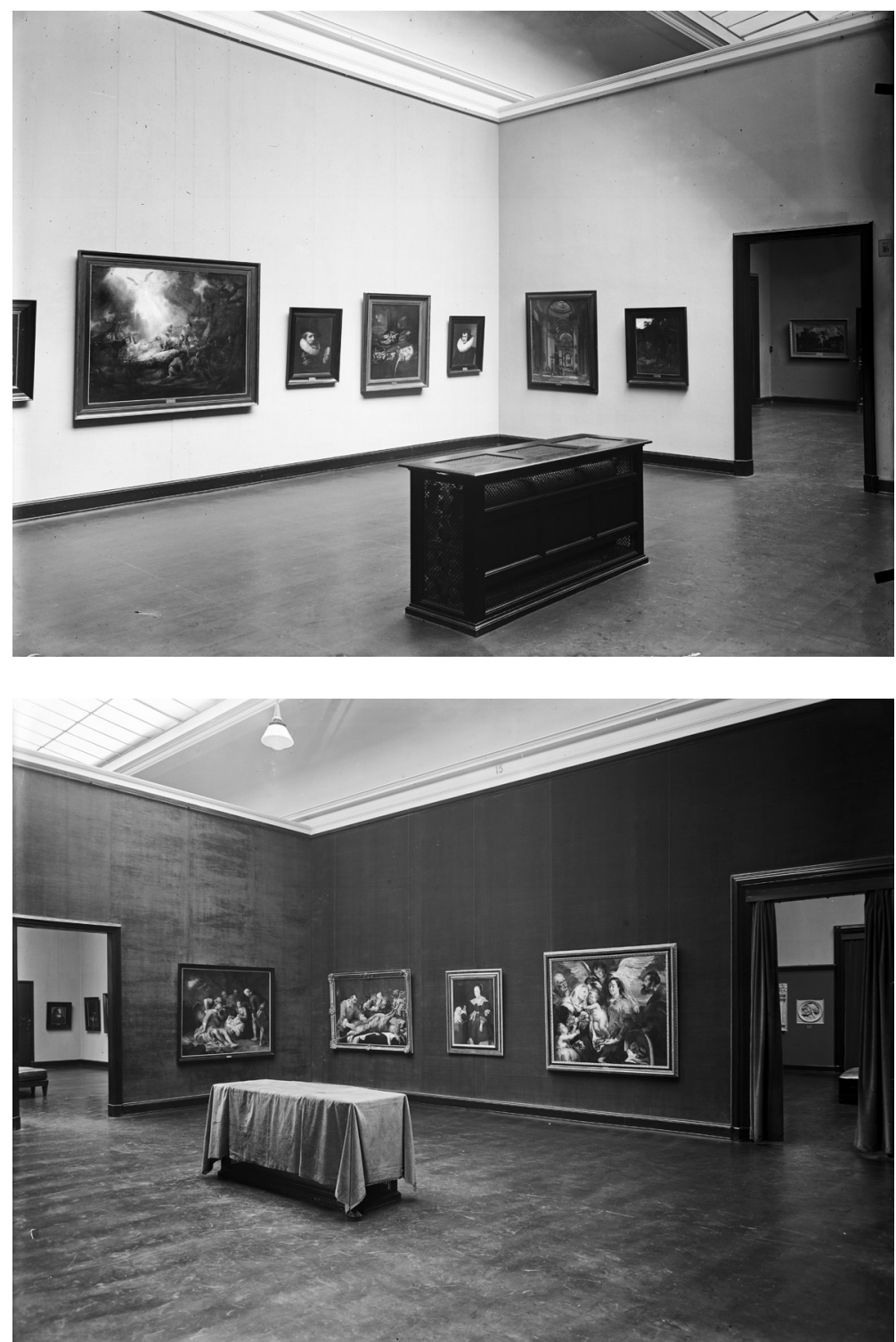


\section{Colour - The activation of the viewer}

The second objective was implemented at the scale of the gallery room and required the emotional mediation of "individual art periods by creating a clear impression and a sense of calm” (Dorner 1924). For this, Dorner used room-specific wall colours to create the setting against which all other elements were to be staged. Steeped in a uniform hue, the rooms intensified the spatial effects imparted by the artworks. By formally organising rooms and their contents as unified milieus, a harmonised context was provided for each period or style. Apart from its formalising function, Dorner also assigned an "activating effect" to colour and employed it as a sensory aid for the instruction of inexpert viewers:

A more passive attitude is seen in galleries where works of art are allowed to "speak for themselves" through being placed, in all their wealth of stylistic variety, against neutral backgrounds. This treatment is more satisfying to the scholar or specialist, who often resists intrusion of a museum director's philosophy, than it is to the general public, which welcomes such intervention as a help towards understanding. But the work of art isolated by its neutral background is a fish out of water. The more passive the attitude, it appears, the more likely the museum to revert to the uniform enfilades of the academic galleries. (Cauman 1958: 83)

It is important to note that Dorner's colour choices were unrelated to the colour preferences of period interiors (although sometimes his choices coincided) (Flacke-Knoch 1986/87: 135). Instead, he abandoned attempts at objective-historical registration in favour of an entirely interpretive history focussed on the evolution of concepts of space. These ideas represented a distinct break with the period room, a widely used display model, which aimed at a truthful reconstruction of historic spaces with furnishings that corresponded to the prevalent historic style of a period.

The use of colour in the context of exhibitions was not unusual at the time, and Monika Flacke-Knoch suggested that it is possible that Dorner was inspired by comparable efforts at the Museum für Kunst und Gewerbe in Hamburg by Max Sauerlandt (1986/87: 145 note 95), who had introduced colour to represent a period's predominant attitude towards life (Klonk 2009: 94). Sauerlandt's colourful appointment of the Hamburg rooms intended to epitomise the specific weight of the period's spiritual timing. Thus, medieval art was shown against a dark blue background accentuating religious seriousness and Baroque art against deep red brown emphasising its splendour. In these instances, correspondences between Sauerlandt's and Dorner's respective colour schemes can be observed. In other instances, however, substantial differences can be detected, particularly in their respective treatments of rooms for Renaissance art, where Dorner used cool whites and greys to represent the sober, geometric character of Renaissance art (Cauman 1958: 89) which contrasts with Sauerlandt's use of an energetic, golden yellow to represent manly, worldly joy (Klonk 2009: 94). But more importantly, fundamental differences in intent can be noted. Dorner's main concern lay in materialising the evolution of the Raumbild as spatial experiences. In that, he differed from Sauerlandt's representative approach that regarded art as the result of the artist's "urge to plastically shape inexpressible feelings" to which a larger "symbolic significance for the feeling of an epoch" was assigned (Sauerlandt 1921: 11). Sauerlandt's plans for the addition of fragrances and music to complete the impression of the artworks too, contrasted with Dorner's much more pragmatic idea of disseminating information via radio broadcasts transmitted by loud speakers (Flacke-Knock 1986/87: 125). 
Dorner's striking arrangements of a few paintings against a surface of continuous colour created a saturated ambiance that pervaded the room - something the visitor would absorb at a glance. This idea of a "total overview" is evident in Dorner's resolve to minimise distractions so that nothing would disturb the atmospheric impact of the space and the immediate formation of a mental image. Everything was kept simple - all elements of the room were subordinated to the larger logic of the atmospheric image. Black linoleum floors minimised the reflection of daylight. Simple custom-designed benches and modern chairs were executed in a black colour to visually merge with the linoleum floors. Designed as low as possible and positioned at the centre of the rooms and at maximum distance from the paintings, these furnishings minimised any interference with the viewing experience. Thus the entire horizontal plane was dematerialised and in its "blackness" almost receded from sight. In the vertical plane, windows were covered with opaque curtains in wall colours to regulate the light, avoid glare and keep out distracting views to the outside world as much as possible, so that these would not compete with the paintings (Cauman 1958: 90-91). With these calculated manipulations, Dorner attained complete control over the internal environment, encouraging the viewer's identification with the themed environment. In contrast, other manipulations were introduced to the opposite effect.

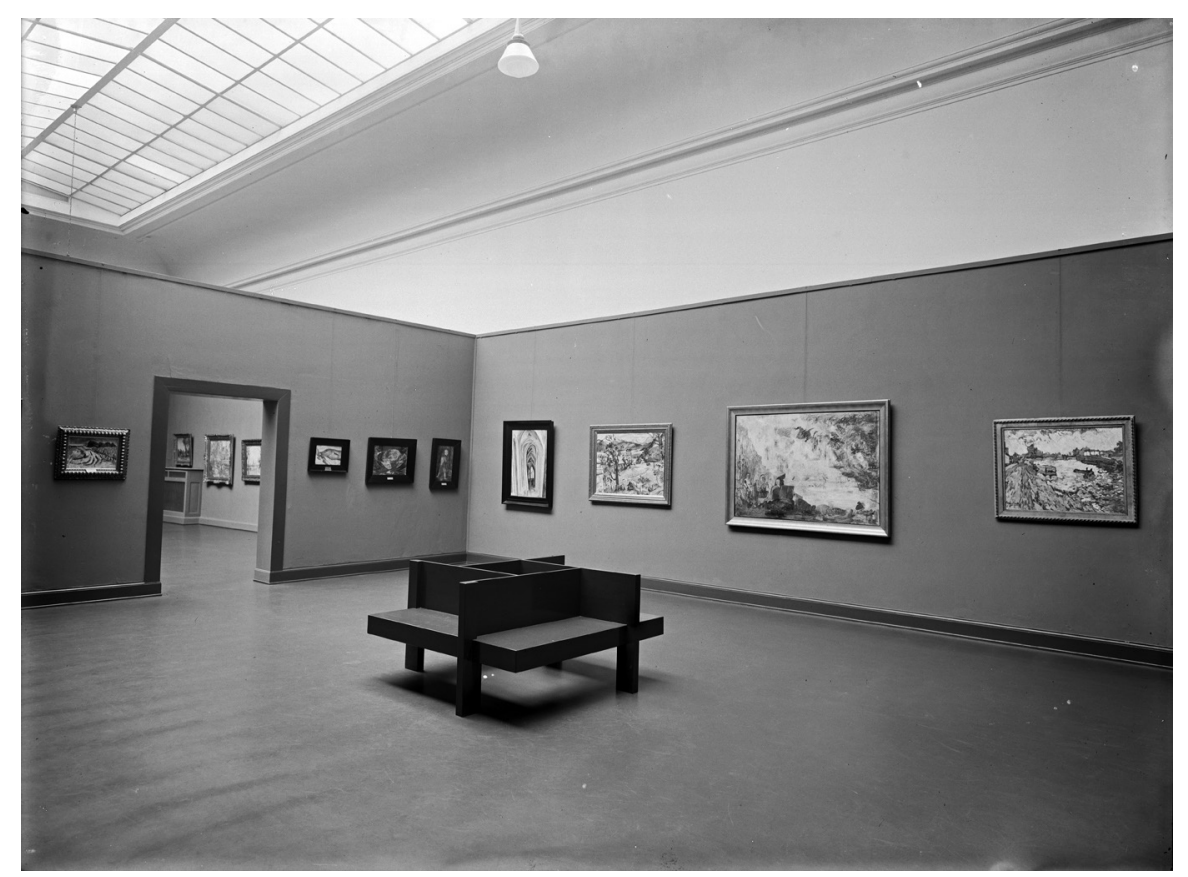

Back and forth -

Atmospheric immersion and awareness of reality

Reviewing the development of space from the Renaissance to the present in his 1934 article Die neue Raumvorstellung in der Bildenden Kunst (The new Imagination of Space in the Plastic Arts), Dorner concluded that the idea of a four-dimensional space and, with it, the "demonstration of a new experience of reality"(37), was most adequately captured with the animating effect and flowing change of perspective in film. It is through this lens that Dorner understood his historical re-organisation of the entire museum, where "a walk through the art collections of the museum unrolls the almost complete development of art from the year 1000 up until our day, and in beholding the artworks, we experience the great
Fig.4 Alexander Dorner. Custom-designed bench in the room for Expressionist art after its reorganisation [photograph courtesy of Niedersächsisches Landesmuseum Hannover Landesgalerie]. 
transformations that have occurred in such profound ways" (Dorner 1927: 9). In using the term "unroll" ("entrollen"), Dorner hinted at a perceived analogy between museum experience and modern film.

Indeed, the Provinzialmuseum's carefully edited itinerary emerged as a succession of differentiated experiences that no longer provided continuity in the fashion of traditional museum narratives. Dorner's careful staging of the gallery spaces provided a sequence of emotional experiences intended to amplify harmony and continuity between different periods on one hand and conflicts and discontinuity on the other hand: in the museum guidebook and other information material, Dorner eliminated potential feelings of ambiguity by making the viewer aware of intended juxtapositions. For example, right upon entering the first room of the art collections, the viewer is alerted about the antagonistic relationship of antique and medieval art: "With the memory of a Greek marble statue, we enter the Romanic hall (1), here we are face to face with a spirit, that relates to antiquity like fire with water." (Dorner ca. 1930, Part 1: 2) Similarly, the fundamental differences between regional variations of Baroque art were evoked together with the contrasting colours and emotions of the respective exhibitions spaces. Augmenting these contrasts, Dorner takes the viewer by the hand, noting:

When we move from the red room of the Flemish into the light grey room of the Dutch, then we come from a magnificent festivity to a silence that is solemn but not gloomy. There are rarely more striking contrasts, and yet both are Baroque. (Dorner ca.1930, Part 2: 7)

Fig.5 Alexander Dorner. Poster in coloured paper hung in doorway between exhibition rooms. [Illustration by author; text translated from German (see Katenhusen \& Reuning 1993:27).

\section{Do not regard this art as in competition with the art of our time; it was created under completely different conditions, but has advanced beyond the art of the previous period in its conception.}

\section{Please consider this and then look at the exhibition...}

(Alexander Dorner) 


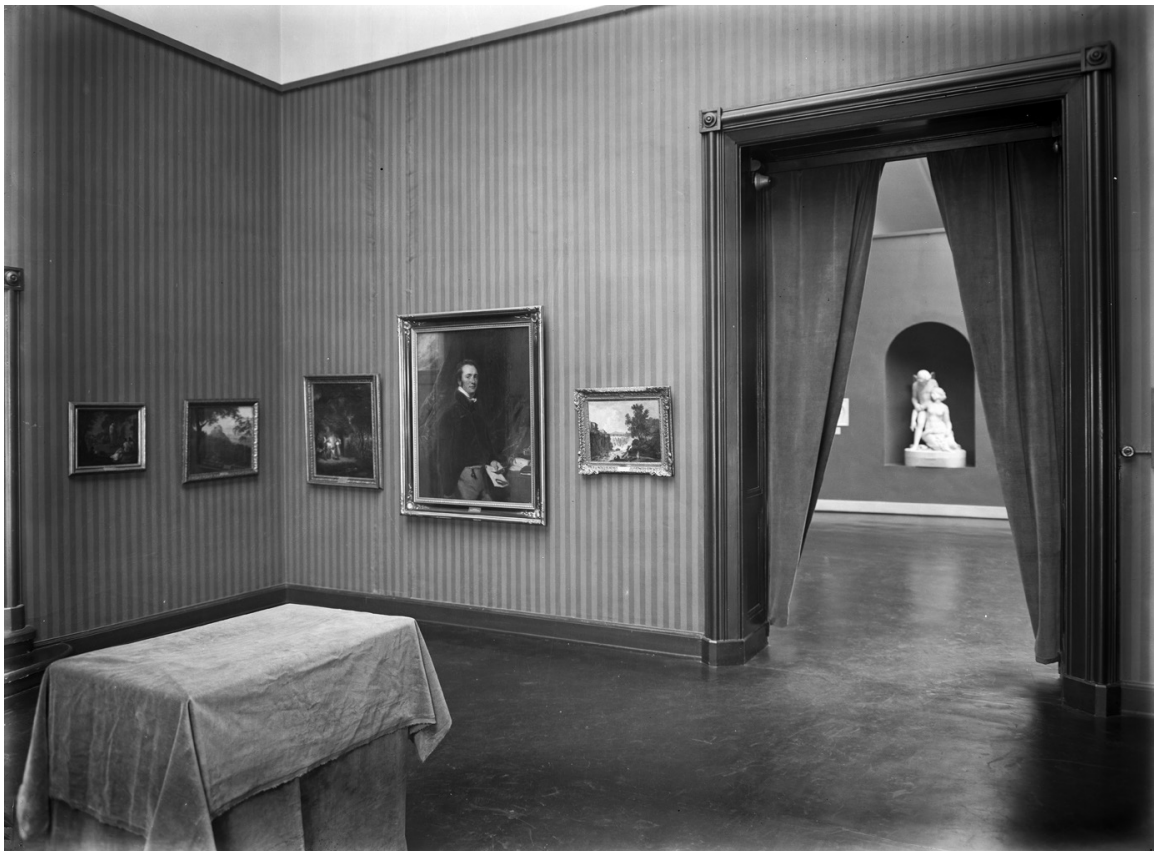

In addition to the colours and the information provided in guide books, other formal and informal devices underlined the respective distinctness or relatedness of rooms and their art. Between contrasting rooms, colour-matched door curtains separated different rooms as discrete milieus and these had to be drawn open upon leaving and entering (see Cauman 1958: 91). Interrupting the viewer's historic identification with a period and foreshadowing change, the curtains functioned as instruments for physical and mental activation. This rupture was augmented by small coloured posters with slogans which were mounted in door openings between rooms. These addressed the viewer directly and gave instructions:

Do not regard this art as in competition with the art of our time; it was created under completely different conditions, but has advanced beyond the art of the previous period in its conception. Please consider this and then look at the exhibition... (Alexander Dorner). (See Katenhusen \& Reuning 1993: 27; Cauman 1958: 93 $)^{9}$

Together, door curtains and posters prompted the viewer's awareness of reality by interrupting the illusory, immersive experience of the atmosphere room. The short slogans complemented the intermittent "sequential locomotion" (Bennett 1995: 43) necessitated by the consecutive arrangement of rooms and offered a form of immediate reading that alluded to the graphic language of mass media encountered in everyday life. Looking back at this strategy 30 years later, Dorner observed: "I can see quite clearly today that my innovations, which involved the arrangement of objects, lettering, etc., were designed to introduce the concepts of modern science into the humane study of art history" (1958: 17). ${ }^{10}$

The experiential changes along the sequence of atmosphere rooms can be compared with what Sloterdijk has described as bathing in alternating pools:

One cannot plunge into an empire's psycho-semantic immersive context without participating in its history. In this sense history is nothing but a diving tank shared with cavorting fellow swimmers, and what is commonly called participation is, seen in this light, merely a naïve dipping
Fig.6 Alexander Dorner. Ramberg

Room after its reorganisation showing door curtains [photograph courtesy of Niedersächsisches Landesmuseum Hannover - Landesgalerie].

9 Cauman mentions the poster text as the last page of a colourful "gallery book" that replaced the earlier guidebook (1958: 93). In contrast, in the exhibition catalogue "überwindung der 'kunst' - Zum 100.

Geburtstag des Kunsthistorikers Alexander Dorner (Hannover, Germany: Sprengel Museum Hannover, 1993: 27), this text is mentioned as an example of a poster hung in the door openings of the atmosphere rooms. Dorner's own notes on the re-organisation mention boxes with notes that would be hung in the door openings (Notizen zur Neuordung Juli 1924, in: Archiv Sprengel Museum Hannover (cited in Flacke 1992: 52).

10 With Dorner's growing collaboration with avant-garde artists and the Bauhaus, the Provinzialmuseum became increasingly implicated in the rise of modern display tactics used in commercial exhibitions, advertising and film, and the associated interest in psycho-perceptual experimentation. These fields of interest had increasingly moved to the forefront of Dorner's thinking from the early 1920 s onward and can be traced in his atmosphere room concept, which, as this study suggests, foreshadowed the interactive environments commissioned by Dorner during the later stages of his re-organisation work from 1926 onward: first, El Lissitzky's Abstract Cabinet in 1927, a display environment, where multicoloured striated walls in modern industria materials, movable paintings and coloured lighting provided dynamic spatial experiences for the viewer; and second, Moholy-Nagy's unrealised multi-media environment - the "Room of the Present" - in which film and photography completely replaced traditional art works (see Gebert \& Hemken 2009).

Lissitzky's demonstrationrooms - the Abstract Cabinet and an earlier version, the Room for Constructivist Art at the Internationale Kunstausstellung Dresden 1926 , have been discussed in detail by numerous authors. In particular see Giedion 1929: 103-106; Gough 2003: 77-128; Hemken 1990: 46-55; Bois 1988: 160-181. 
into a one-dimensional context (while so-called critique can only be learnt through immersive changes, through bathing in alternating pools or contexts). (2011 (2006):105)

In the back and forth between immersion and self-awareness, Dorner recognised the phenomenon of what he referred to as "an evolutionary psychology in action" (Cauman 1958: 88). The alternation between empathic identification on one hand, and rational recognition of reality on the other hand, materialised as the actual innovation of Dorner's curatorial ethos. With it, he recast fundamental assumptions about the reception of art as either rational (via distanced contemplation and visual) or empathic (via experiential immersion and haptic) by providing immersive changes and interruptions that encouraged a critical reception rather than the delivery of pre-mediated content.

\section{References}

Bennett, T. (1995). The Birth of the Museum. London, England: Routledge.

Bois, Y.-A. (April 1988). El Lissitzky: Radical Reversibility. Art in America, 76(4), 160-181.

Cauman, S. (1958). The Living Museum: Experiences of an Art Historian and Museum Director Alexander Dorner. New York, NY: New York University Press.

Dorner, A. (1923). Die Romanische Baukunst in Sachsen und Westfalen. Leipzig, Germany: E. A. Seemann.

Dorner, A. (15. September 1924). Was sollen heute Kunst-Museen? Der Sammler. Wochenzeitschrift für alte und neue Kunst, 14. Jahrgang (Heft 17).

Dorner, A. (1925). Erwerbungen neuer Kunst im Museum der Provinz Hannover. Der Cicerone, XVII, 1157-1162.

Dorner, A. (1927). Meisterwerke aus dem Provinzial-Museum in Hannover. Berlin, Germany: Werner Kube Verlag.

Dorner, A. (1958). The way beyond 'art' (revised ed.). New York, NY: New York University Press. Dorner, A. (ca.1930). Amtlicher Führer durch die Kunstsammlungen des Provinzial-Museums Hannover. Berlin, Germany: Julius Bard.

Dorner, A. (1932). Die neue Raumvorstellug in der Bildenden Kunst. Museum der Gegenwart, Volume II, 1931-32, 30-37.

Flacke-Knoch, M. (1986/1987). Das Museum in der Weimarer Republik: Alexander Dorner im Provinzialmuseum Hannover. In J. Bracker (Ed.), Beiträge Zur Deutschen Volks- Und Altertumskunde (pp.125-147). Hamburg, Germany: Verlag Hamburger Museumsverein.

Flacke, M. (1992). Alexander Dorner. Köln, Germany: Böhlau Verlag.

Flacke, M. (1993). Die Neuordnung der Deutschen Museen in der Weimarer Republik. In I. Katenhusen and R. Reuning (Eds.), Überwindung Der 'Kunst' - Zum 100. Geburtstag Des Kunsthistorikers Alexander Dorner (pp. 47-54). Hannover, Germany: Sprengel Museum Hannover.

Gebert, J., \& Hemken, K.-U. (2009). Der Raum der Gegenwart: Die Ordnung von Apparaten und Exponaten. In U.Gartner, K.-U. Hemken, K. U. Schierz (Eds.), Kunst Licht Spiele: Lichtästhetik der klassischen Avantgarde (pp.138-155). Bielefeld, Germany: Kerber.

Giedion, S. (1929). Lebendiges Museum. Der Cicerone, XXI (4), 103-106.

Gough, M. (2003). Constructivism Disoriented: El Lissitzky’s Dresden and Hannover Demonstrationsräume. In N. Perloff, B. Reed (Eds.), Situating El Lissitzky: Vitebsk Berlin Moscow. Los Angeles, CA: Getty Research Institute. 
Hemken, K.-U. (1990). Pan-Europe and German art: El Lissitzky at the 1926 Internationale Kunstaustellung in Dresden. In Jan Bout et al. El Lissitzky 1890-1941: architect, painter, photographer, typographer (pp. 46-55). Eindhoven, Netherlands: Municipal van Abbemuseum. Henderson, L. D. (1990). The Image and Imagination of the Fourth Dimension in TwentiethCentury Art and Culture. Configurations, 17(1), 131-160.

Joachimides, A. (2001). Die Museumsreformbewegung in Deutschland und die Entstehung des modernen Museums 1880-1940. Dresden, Germany: Verlag der Kunst.

Kállai, E. (1922). El Lissitzky. Das Kunstblatt, 6(1).

Katenhusen, I. (1993). Zwischen Lob und Tadel: Zur Beurteilung der Arbeit Alexander Dorner's in Hannover. In I. Katenhusen \& R. Reuning (Eds.), Überwindung Der 'Kunst' - Zum 100. Geburtstag Des Kunsthistorikers Alexander Dorner (pp. 71-78). Hannover, Germany: Sprengel Museum Hannover.

Katenhusen, I. \& Reuning, R. (Eds.) (1993), Überwindung Der 'Kunst' - Zum 100. Geburtstag Des Kunsthistorikers Alexander Dorner. Hannover, Germany: Sprengel Museum Hannover.

Mai, E. (2010). Die Deutschen Kunstakademien im 19. Jahrhundert: Künstlerausbildung zwischen Tradition und Avantgarde. Köln, Germany: Böhlau.

Newbery, T. J., Bisacca, G., \& Kanter, L. B. (1990). Italian Renasissance Frames - exhibition at the Metropolitan Museum of Art New York 5 June - 2 September 1990, New York, NY: Metropolitan Museum of Art.

Riegl, A. (1908). Die Enstehung der Barockkunst in Rom: Akademische Vorlesungen gehalten von Alois Riegl, aus seinen hinterlassenen Papieren. Wien, Austria: Anton Schroll \& Co.

Sauerlandt, M.(1921). Emil Nolde. München, Germany: K. Wolff.

Schivelbusch, W. (1995). Disenchanted Night: The Industrialisation of light in the nineteenth century. Berkeley, CA: University of California Press.

Sloterdijk, P. (2011). Architecture as an art of immersion. Interstices: Journal of Architecture and Related Arts 12, 106-109.

Scholl, J. (1995). Funktionen der Farbe. Das Kronprinzenpalais als farbiges Museum. In A. Joachimides, S. Kuhrau, V. Vahrson, N. Bernau, Museumsinszenierungen: Zur Geschichte der Institution des Kunstmuseums - Die Berliner Museumslandschaft 1830-1990, Dresden, Germany: Verlag der Kunst.

Taut, B. (1918). Arbeitsrat für Kunst in Berlin. Mitteilungen des deutschen Werkbundes 4, 14-15. Vöhringer, M. (2007). Avantgarde und Psychotechnik: Wissenschaft Kunst und Technik der Wahrnehmungsexperimente in der frühen Sowjetunion. Göttingen, Germany: Wallstein Verlag.

Translations from German by author unless otherwise indicated. 